\title{
Reduto do Humano: Identidade Narrativa e a Humanização da Saúde
}

\author{
Doppenschmitt, Marcelo Souza Koch Vaz \\ Faculdade de Direito de São Bernardo do Campo — marcelokoch@gmail.com
}

Introdução: a necessidade de humanização da saúde é amplamente reconhecida desde ao menos a segunda metade do século XX. por esta razão, recorre-se às humanidades a fim de se promover a humanização dos profissionais da saúde, notadamente em sua formação. no entanto, as humanidades são elas mesmas marcadas por um traço anti-humanista em busca de uma objetividade que lhes faltaria para adquirir o estatuto de ciência, o que deu ensejo ao surgimento de abordagens para as quais seu objeto de estudo não é o próprio homem, a pessoa, o sujeito humano, mas antes algo que está por trás dele e, de algum modo, permite-nos explicar o fenômeno humano. Nessa linha, encontram-se os autores chamados de mestres da suspeita que encetaram abordagens nas quais 0 fenômeno humano é algo que precisa ser explicado por outros elementos: a história, a estrutura linguística, o inconsciente. por outro lado, uma outra abordagem fortaleceu-se nas últimas décadas tendo por objetivo a recuperação do sujeito humano, este sendo seu objeto principal. Decerto que não se trata de voltar a uma concepção clássica de sujeito tal como foi concebida no início da modernidade como em sua versão cartesiana na qual o sujeito é entendido como coisa, objeto. Não se trata, tampouco, de negar a existência ou relevância da ação do sujeito da perspectiva sociológica, psicológica ou filosófica. Entre estas duas posições extremas, é possível pensar a identidade pessoal e moral em uma perspectiva narrativa - é possível falar em identidade narrativa - como abordagem fundamental para se pensar a humanização das humanidades e, por conseguinte, do seu papel na formação dos profissionais de saúde. Objetivos: o presente trabalho tem por objetivo elucidar o que significa o emprego do termo humanizar no campo das humanidades e suas repercussões na formação do profissional de saúde. de modo mais específico, pretende-se demonstrar o papel que o conceito de identidade narrativa joga nesta humanização e sua importância, por exemplo, nas reflexões a respeito da relação entre médico e paciente. Métodos: para alcançar o propósito do trabalho, recorreu-se à análise conceitual de textos em uma abordagem ético-filosófica. Resultados: Algumas abordagens em humanidades que nutrem a suspeita em relação à pessoa humana, ressaltam aspectos de controle social - relações econômicas, de poder, de desejo - que presidiriam as ações humanas. a despeito de sua relevância e utilidade, estas abordagens falham em compreender a ação do sujeito no reduto do humano: como o sujeito compreende a sim mesmo enquanto agente moral e como esta compreensão implica o mundo, os outros, a história, a cultura, o que se apresenta inexoravelmente em uma forma narrativa. Conclusão: a fim de que as humanidades contribuam efetivamente para a humanização na saúde, não é desprezível que antes pensemos o significado dessa humanização ou do humanismo nas abordagens dos estudos das humanidades.

Doppenschmitt, Marcelo Souza Koch Vaz. Reduto do Humano: Identidade Narrativa e a Humanização da Saúde. In: Anais do Congresso Internacional de Humanidades \& Humanização em Saúde [= Blucher Medical Proceedings, num.2, vol.1]. São Paulo: Editora Blucher, 2014. ISSN 2357-7282

DOI 10.5151/medpro-cihhs-10574 